УДК 618.173:616.71-007.234-085

DOI 10.11603/24116-4944.2019.1.10204

\author{
๑І. М. Щербина, Л. В. Потапова, О. П. Ліпко, О. І. Скорбач \\ Харківсъкий національний медичний університет
}

\title{
КОРЕКЦІЯ ОПОРНО-РУХОВИХ ПОРУШЕНЬ У ЖІНОК В ПЕРИМЕНОПАУЗІ
}

Мета дослідження - вивчення ознак остеопорозу в жінок перименопаузального віку, розробка ефективних методів його лікування з попередженням ускладнень та покращенням якості життя.

Матеріали та методи. Під наглядом перебували 52 жінки віком від 50-60 років. Перша група - хворі 3 легким (I) ступенем остеопенії (19 (36,6 \%) пацієнток), друга - з середнім (II) ступенем остеопенії (15 (28,8 \%) пацієнток), третя (III) - Хворі на остеопороз (18 (34,6 \%) пацієнток). Контрольну групу склали 52 жінки з фізіологічним перебігом перименопаузи. Усім жінкам проводили дослідження мінеральної щільності кісткової тканини (денситометрія), дослідження мінерального балансу, визначення в сироватці крові автоантитіл до колагену та еластину.

Результати дослідження та їх обговорення. За результатами комп'ютерної рентгеностеоденситометрії, у 19 (36,5 \%)

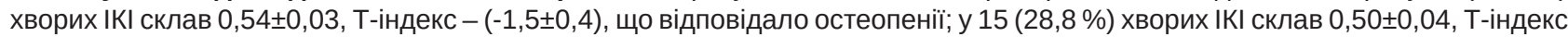

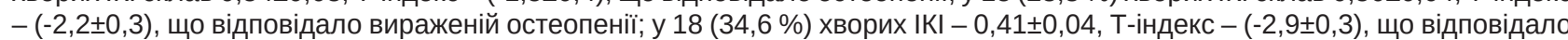
остеопорозу. В обстежених жінок зниження рівня загального кальцію і магнію сироватки крові корелює з розвитком порушень опорно-рухової системи в перименопаузі. У жінок з остеопорозом визначаються в достовірно значущих кількостях антитіла до колагену й еластину. Для лікування жінок застосовували схему лікувальних заходів (медикаментозні та немедикаментозні), що мала суттєвий позитивний ефект.

Висновки. Ознаки опорно-рухових порушень у жінок в перименопаузі патогенетично пов'язані з віковими порушеннями в репродуктивній системі. Важливими елементами нових підходів цих порушень та підвищення якості життя цих пацієнток $\epsilon$ включення в терапевтичний комплекс вітамінів групи D та селективних модуляторів естрогенових рецепторів. Розроблена схема лікувальних заходів з урахуванням патогенетичних особливостей опорно-рухових порушень приводить до більш раннього і стабільного клінічного ефекту, не викликає змін у репродуктивних органах, що достатньо небезпечно в перименопаузі.

Ключові слова: корекція перименопаузальних порушень; остеопенія; остеопороз.

КОРРЕКЦИЯ ОПОРНО-ДВИГАТЕЛЬНЫХ НАРУШЕНИЙ У ЖЕНЩИН В ПЕРИМЕНОПАУЗЕ

Цель исследования - изучение признаков остеопороза у женщин перименопаузального возраста, разработка эфреективных методов его лечения с предупреждением осложнений и улучшением качества жизни.

Материалы и методы. Под наблюдением находились 52 женщины в возрасте от 50-60 лет. Первая группа - больные с легкой (I) степенью остеопении (19 (36,6 \%) пациенток), вторая - со средней (II) степенью остеопении (15 (28,8 \%) пациенток), третья (III) - с остеопорозом (18 (34,6 \%) пациенток). Контрольную группу составили 52 женщины с фризиологическим течением перименопаузы. Всем женщинам проводились исследования минеральной плотности костной ткани (денситометрия), исследования минерального баланса, определение в сыворотке крови аутоантител к коллагену и эластину.

Результаты исследования и их обсуждение. По результатам компьютерной рентгеностеоденситометрии, у 19

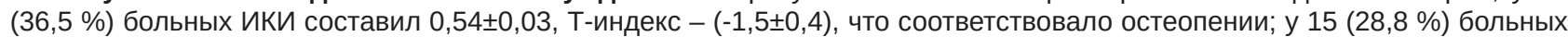

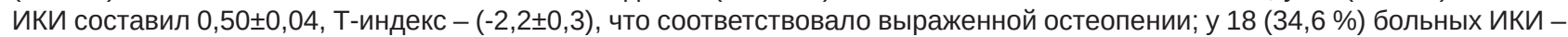

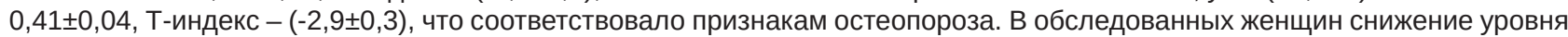
общего кальция и магния сыворотки крови коррелирует с развитием нарушений опорно-двигательной системы в перименопаузе. У женщин с остеопорозом определяются в достоверно значимых количествах антитела к коллагену и эластину. Для лечения женщин применяли схему лечебных мероприятий (медикаментозные и немедикаментозные), которая имела существенный положительный эфрфект.

Выводы. Признаки опорно-двигательных нарушений у женщин в перименопаузе патогенетически связаны с возрастными нарушениями в репродуктивной системе. Важными элементами новых подходов к коррекции этих нарушений и повышения качества жизни пациенток является включение в терапевтический комплекс витаминов группы D и селективных модуляторов эстрогеновых рецепторов. Разработанная схема лечебных мероприятий с учетом патогенетических особенностей опорно-двигательных нарушений приводит к более раннему и стабильному клиническому эфффекту, не вызывает изменений в репродуктивных органах, что достаточно небезопасно в перименопаузе.

Ключевые слова: коррекция перименопаузальных нарушений; остеопения; остеопороз.

TREATMENT OF MUSCULOSKELETAL DISORDERS IN WOMEN IN PERIMENOPAUSE

The aim of the study - to investigate the signs of osteoporosis in women in perimenopausal age. Furthermore, we aimed to develop an effective method of treatment of osteroporosis in perimenopausal women and design strategies to prevent the complications in order to improve the quality of life.

Materials and Methods. The study included 52 women aged 50-60 years. The group 1 constisted of patients with mild (I) degree of osteopenia (19 (36.6\%) patients), the group 2 included patients with moderate (II) degree of osteopenia (15 (28.8\%) patients), the group 3 (III) comprised of patients with osteoporosis ( 18 (34.6\%) patients). The control group consisted of 52 women in perimenopause phase. All women were assessed based on the following parameters: bone mineral density (densitometry), mineral balance and the level of antibodies to collagen and elastin.

Results and Discussion. The X-ray densitometry revealed that in 19 (36.5\%) patients cortical thickness index was $(0.54 \pm 0.03)$ and the T-index was (-1.5 \pm 0.4$)$, which corresponded to osteopenia. In 15 (28.8\%) patients cortical thickness index was $(0.50 \pm 0.04)$, the 
T-index was (-2.2 \pm 0.3$)$, which corresponded to severe osteopenia; finally, in the 18 (34.6\%) patients examined the cortical thickness index was $(0.41 \pm 0.04)$ and T-index was $(-2.9 \pm 0.3)$, which indicated the onset of osteoporosis. The total calcium and magnesium levels were decreased in all patients enrolled in the study, which correlated with the development of musculoskeletal disorders prevalent during perimenopause. We determined the antibody to collagen and elastin in patients who exhibited signs of osteoporosis. Women enrolled in the study underwent the therapy which was specifically designed for this study and resulted in significant improvement.

Conclusions. Signs of musculoskeletal disorders in women in perimenopausal stage are associated with age-related disorders of the reproductive system. It is important to focus on improving the quality of life of these patients. The therapy proposed includes a combination of vitamin $\mathrm{D}$ and selective estrogen receptor modulators. The therapy designed in this study results in more effective and stable clinical outcomes for patients.

Key words: treatment of perimenopausal disorders; osteopenia; osteoporosis.

ВстУп. У цілому світі складається тенденція до збільшення кількості жінок зрілого та похилого віку. В розвинених країнах процентне співвідношення жінок, старших 50 років, за останнє сторіччя зросло втричі. В Україні жіноче населення цього віку складає понад $35 \%$ і майже п'яту частину всього населення країни [1]. Перименопаузальний період являє собою фізіологічний стан жінки, впродовж якого на тлі загальних змін організму домінують інволютивні процеси в репродуктивній системі з переходом на інший режим існування. Перименопауза збігається з періодом найбільшої професійної активності жінки, що викликає підвищений інтерес вчених не тільки з медичної, але і з соціальної точки зору.

Достатньо складні і різноманітні патогенетичні ланки перименопаузальних розладів. Ендокринно-вегетативний криз, що виникає в результаті десріциту естрогенів, призводить до порушень адаптаційних процесів, які, у свою чергу, сигналізуються багатьма системними змінами в організмі і ведуть до окремих синдромів: нейровегетативного, психоемоційного, метаболічного, урогенітального, опорно-рухового [2, 3].

Виникнення цих симптомокомплексів має загальну основу, але і окремі етіопатогенетичні шляхи розвитку, виникає як ізольовано, так і в поєднанні з екстрагенітальною патологією.

Одним із поширених розладів перименопаузального синдрому $€$ остеопороз. Це системне захворювання скелета, що характеризується зниженням маси кісток та порушенням мікроархітектоніки кісткової тканини, внаслідок чого значно підвищується крихкість кісток. У цьому випадку мова йде про первинний остеопороз, що виникає внаслідок обмінно-ендокринно-імунних порушень, притаманних перименопаузі [4]. Особливої актуальності ця проблема набула у зв'язку з високою розповсюдженістю і тяжкими наслідками (переломи кінцівок, хребта, артропатії, едентулізм), що призводять до непрацездатності, різкого погіршення якості життя, підвищення смертності, тобто ця проблема має величезне медико-соціальне економічне значення [5].

Аналіз багатьох досліджень дозволяє розглядати проблему вікових опорно-рухових порушень достатньо чітко і послідовно, що дає можливість надавати жінкам лікувальну та профрілактичну допомогу, але різноманітні терапевтичні, медикаментозні й немедикаментозні схеми часто містять препарати складної комбінованої структури, що мають загрозливі побічні ефректи та протипоказання [6]. Практикуючі лікарі-гінекологи призначають такі схеми неохоче і з небезпекою.

МЕТА ДОСЛІДЖЕННЯ - вивчення ознак остеопорозу в жінок перименопаузального віку, розробка ефективних методів його лікування з попередженням ускладнень та покращенням якості життя.

МАТЕРІАЛИ ТА МЕТОДИ. Під наглядом перебували

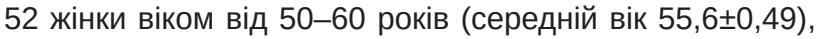
які поділялися на 3 групи залежно від ступеня тяжкості опорно-рухових порушень. Перша група - хворі з легким (I) ступенем остеопенії (19 (36,6 \%) пацієнток), друга - 3 середнім (II) ступенем остеопенії (15 (28,8 \%) пацієнток), третя (III) - Хворі на остеопороз (18 (34,6 \%) пацієнток). Контрольну групу склали 52 жінки з фрізіологічним перебігом перименопаузи. Критеріями ступеня тяжкості були дані досліджень мінеральної щільності кісткової тканини (денситометрія), скарги, об'єктивне дослідження жінок. Загальними скаргами хворих були періодичні болі у крижовій та поперековій ділянці, особливо після фрізичних навантажень, болі в кістках таза, великих суглобах, ребрах, потилиці, шиї. У багатьох пацієнток були зміни росту, сутулість. В анамнезі 20 (38,5 \%) хворих мали перелом променевої кістки, 8 (15,4 \%) - плечової кістки, 6 (11,5 \%) - перелом хребта. У 14 (56,0 \%) пацієнток були ознаки пародонтозу.

Всім пацієнткам було проведене загальноклінічне дослідження. Для діагностики опорно-рухових порушень використовували метод оцінки структурно-фрункціонального стану кісткової тканини за допомогою комп'ютерної рентгеностеоденситометрії з програмним забезпеченням «АРМ-Остеолог», розробленим у відділенні клінічної фрізіології і патології опорно-рухового апарату Інституту геронтології АМН України (Патент № 200101102115 від 11.01.2001 р.).

Визначали такі параметри, як: показники кортикальних індексів (KI) - II, III, IV, V (в умовних одиницях); інтегральний кортикальний індекс (IKI); індекс маси тіла; показники жорсткості; еквівалент щільності; показник яскравості; щільність реальна; критерій T (SD); критерій Z (SD). Всі вимірювання були зроблені одним і тим же оператором.

Відповідно до рекомендацій ВООЗ, ступінь зміни мінеральної щільності кісткової тканини оцінювали за Т-індексом та інтегральним кортикальним індексом.

Дослідження мінерального балансу проводили шляхом оцінки рівня загального кальцію $\left(\mathrm{Ca}_{\text {заг. }}\right)$, фросфоро неорганічного $\left(\mathrm{P}_{\text {неорг. }}\right)$ і магнію $(\mathrm{Mg})$ фротометричним методом за допомогою стандартних наборів НВП «ФілісистДіагностика» (Україна).

Також у сироватці крові визначали автоантитіла до колагену та еластину методом ІФА, використовуючи стандартні набори тест-системи «Гранум» (Харків).

Статистичну обробку результатів проводили з використанням пакета аналізу даних «Microsoft Excel» та програми 
«Biostat» із застосуванням критерію Стьюдента. Результати досліджень вважалися достовірними при р<0,05.

РЕЗУЛЬТАТИ ДОСЛІДЖЕННЯ ТА ЇХ ОБГОВОРЕННЯ. Оцінка змін показників мінеральної щільності кісткової тканини показала таке: при рентгенологічному дослідженні хребта у 24 (46,2 \%) жінок діагностовано остеохондроз, у 18 (34,6 \%) - виявлені зміни, які характерні для остеопорозу (витончення поперечних трабекул, потовщення поздовжніх трабекул). У 10 (19,2 \%) виявлені рентгенологічні зміни, які характерні для остеоартрозу в дуговідросткових і крижово-клубових суглобах. Серед них пацієнтки з тазостегново-поперековим синдромом, що являє собою стійку сукупність дегенеративно-деструктивних порушень у попереково-крижовому відділі хребта, викликаних змінами біомеханіки таза у пацієнток з десрормуючим остеоартрозом кульшового суглоба, який діагностовано у 2 (3,8 \%) жінок.

За результатами комп'ютерної рентгеностеоденситометрії, пацієнтки розподілилися таким чином: у 19

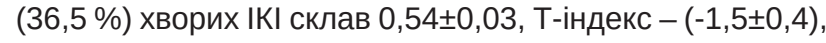
що відповідало остеопенії; у 15 (28,8 \%) хворих IKI склав

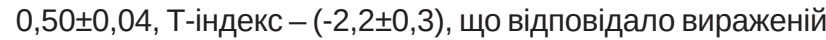

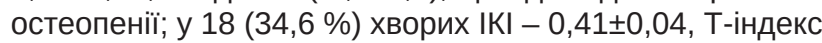

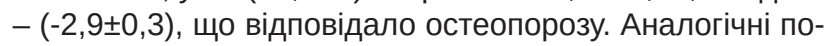
казники в жінок із фрізіологічною перименопаузою - IKI $-(0,56 \pm 0,04)$.

Рівень мікроелементів в обстежених жінок виявив наступне: достовірне зниження середніх значень концентрації загального кальцію і магнію у жінок з порушеннями опорно-рухової системи (за даними денситометрії) порівняно $з$ жінками контрольної групи з нормальним рівнем МщКТ, отриманий фракт вказує на те, що зниження рівня загального кальцію і магнію сироватки крові корелює 3 розвитком порушень опорно-рухової системи в перименопаузі (табл. 1).

Вміст автоантитіл до колагену та еластину в пацієнток досліджуваних груп виявився таким (табл. 2).

Привертає увагу те, що в жінок з остеопорозом, на відміну від жінок з остеопенією, визначаються в достовірно значущих кількостях антитіла до колагену й еластину.

Поява в сироватці крові підвищеної кількості автоантитіл до будь-яких тканин пов'язана з порушенням обміну речовин та імунно-ендокринних зв'язків, а також із зниженням регуляторної фрункції імунної системи. Автоантитіла через опосередковувані ними реакції здатні викликати у тканинах імунопатологічні процеси, порушувати структурну цілісність органів або тканин та збої у їх функціонуванні.

Для лікування жінок з опорно-руховими порушеннями в перименопаузі ми застосували наступну схему лікувальних заходів, що мала суттєвий позитивний есрект і була достатньо адекватною та безпечною для здоров'я жінок.

Важливим компонентом терапії було раціональне харчування (перевага рослинної їжі, збагаченої клітковиною, бобові культури, хліб з цільними зернами пшениці, насіння соняшника, ягоди, соєві продукти, збагачені фрітоестрогенами). Крім овочів та фрруктів, у раціон харчування включали молочні продукти, рослинні жири, знежирене м'ясо, птицю, рибу. 3 немедикаментозних методів використовували гідротерапію, загальні хвойні ванни, гарячі ножні ванни, бальнеотерапію в звичній кліматичній зоні (перлинні, кисневі, радонові, йодобромні ванни), рефлексотерапію.

Пацієнтки з опорно-руховими порушеннями, крім зазначених немедикаментозних заходів, отримували вітамін D - холекальциферол, який призначали по 1 капсулі (50 мг) на добу внутрішньо протягом 2-х місяців. Найважливішою фрункцією цієї речовини є регулювання метаболізму кальцію та фоосфратів, що сприяє фрізіологічній мінералізації кісток, абсорбції кальцію та фросфратів з кишечнику. Вітамін D бере участь у функціонуванні імунної системи, особливо у виробництві лімсрокінів. Завдяки комплексній дії холекальциферол позитивно впливає на скелетно-м'язову систему в жінок у перименопаузі на тлі естрогенного десріциту та метаболічних порушень.

Також у терапію включали ралоксифену гідрохлорид - селективний модулятор естрогенових рецепторів, що діє як агоніст на нерепродуктивні органи і як антагоніст на репродуктивні. Підвищує концентрацію глобулінів, що зв'язують статеві гормони, нормалізує процеси резорбції в кістках, підвищує їх масу, стабілізує ліпідний обмін. Препарат застосовували в дозі 60 мг на добу, внутрішньо, протягом 2-х місяців.

Вже через 3-4 тижні після початку лікування всі жінки відзначили покращення самопочуття. Зменшення болю в

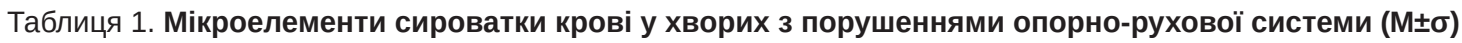

\begin{tabular}{|l|c|c|c||}
\hline \multicolumn{1}{|c|}{ Групи обстежених } & $\begin{array}{c}\mathrm{Ca}_{\text {заг' }} \\
\text { ммоль/л }\end{array}$ & $\begin{array}{c}\mathrm{P}_{\text {неорг' }} \\
\text { ммоль/л }\end{array}$ & $\begin{array}{c}\text { Mg, } \\
\text { ммоль/л }\end{array}$ \\
\hline Хворі з легким ступенем остеопенії $(\mathrm{n}=19)$ & $2,21 \pm 0,18^{*}$ & $0,84 \pm 0,09$ & $0,82 \pm 0,05^{*}$ \\
\hline Хворі із середнім ступенем остеопенії $(\mathrm{n}=15)$ & $2,22 \pm 0,16^{*}$ & $0,86 \pm 0,08$ & $0,80 \pm 0,04^{*}$ \\
\hline Хворі на остеопороз $(\mathrm{n}=18)$ & $2,20 \pm 0,19^{*}$ & $0,87 \pm 0,06$ & $0,79 \pm 0,06^{*}$ \\
\hline Контрольна група $(\mathrm{n}=52)$ & $2,53 \pm 0,2$ & $1,03 \pm 0,09$ & $0,91 \pm 0,09$ \\
\hline
\end{tabular}

Примітка. * p<0,05 - достовірність відмінностей між показниками хворих та контрольної групи.

Таблиця 2. Рівень вмісту автоантитіл у сироватці крові хворих з опорно-руховими порушеннями

\begin{tabular}{|l|c|c|c|c|}
\hline Показники, відн. од. & $\begin{array}{c}\text { Хворі з легким ступенем } \\
\text { остеопенії }(\mathrm{n}=19)\end{array}$ & $\begin{array}{c}\text { Хворі із середнім ступенем } \\
\text { остеопенії }(\mathrm{n}=15)\end{array}$ & $\begin{array}{c}\text { Хворі на остеопороз } \\
(\mathrm{n}=18)\end{array}$ & $\begin{array}{c}\text { Контрольна група } \\
(\mathrm{n}=52)\end{array}$ \\
\hline АТ до колагену & $1,2 \pm 0,1$ & $1,4 \pm 0,1$ & $1,6 \pm 0,2^{\star}$ & $1,1 \pm 0,1$ \\
\hline АТ до еластину & $1,2 \pm 0,1$ & $1,3 \pm 0,1$ & $1,4 \pm 0,2^{\star}$ & $1,1 \pm 0,1$ \\
\hline
\end{tabular}

Примітка. * p<0,05 - достовірність відмінностей між показниками хворих та контрольної групи. 
ділянках суглобів у 35 (67,3 \%) жінок, у 49 (94,2 \%) жінок зменшення болю у хребті та попереку. Рецидиви пародонтозу були відсутні.

Через 2 місяці терапії, тобто після закінчення курсу лікування, на біль у ділянці кісток таза, хребта, суглобів скаржилися 12 (23,1%) жінок, у цих хворих періодичність і вираженість больового синдрому зменшилась. Відзначилося підвищення толерантності до фрізичного навантаження. Відсутні загострення пародонтозу та випадки переломів.

Аналізуючи дані денситометрії у пацієнток після закінчення курсу лікування, відзначено, що у 7 (13,5 \%)

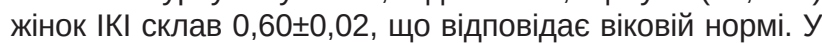

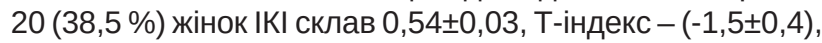
що відповідало остеопенії. У 15 (28,8 \%) пацієнток IKI був $0,49 \pm 0,02$, Т-індекс - $(-2,2 \pm 0,3)$, що відповідало вираженій остеопенії. У 10 (19,2\%) хворих IKI склав 0,42 $\pm 0,04$

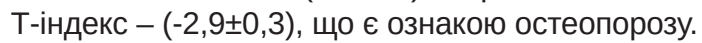

Після закінчення курсу лікування рівень мікроелементів у пацієнток відповідав значенням вікової норми.

Через 2 місяці після лікування в жінок із вираженою остеопенією та остеопорозом визначилося достовірне зниження автоантитіл до колагену $(1,1 \pm 0,1)$ та еластину $(1,1 \pm 0,1)$, що вказує на нормалізацію обмінних процесів, як в організмі в цілому, так, зокрема, в кістковій тканині.

ВисновкИ. Ознаки опорно-рухових порушень у жінок в перименопаузі патогенетично пов'язані з віковими порушеннями в репродуктивній системі. Важливими елементами нових підходів цих порушень та підвищення якості життя цих пацієнток є включення в терапевтичний комплекс вітамінів групи D та селективних модуляторів естрогенових рецепторів. Розроблена схема лікувальних заходів з урахуванням патогенетичних особливостей опорно-рухових порушень приводить до більш раннього і стабільного клінічного ефекту, не викликає змін у репродуктивних органах, що достатньо небезпечно в перименопаузі.

ПЕРСПЕКТИВИ ПОДАЛЬШИХ ДОСЛІДЖЕНЬ. У цілому, подальше вивчення та оцінка багатьох аспектів патогенезу опорно-рухових порушень у жінок в перименопаузі дозволить удосконалити терапевтичні підходи до вирішення проблем здоров'я жінки і визначення медикосоціальних аспектів підвищення якості життя в перехідному та старечому віці.

\section{СПИСОК ЛІТЕРАТУРИ}

1. Дністрянська А. П. Комплексна корекція клінічних проявів перименопаузального періоду у жінок / А. П. Дністрянська // Здоровье женщины. - 2014. - № 10. - С. 157-162.

2 Современный подход к проблеме остеопороза у женщин, находящихся в климактерическом периоде / П. Н. Веропотвелян, Н. П. Веропотвелян, Е. А. Маркин, А. С. Сагань // Медицинские аспекты здоровья женщины. - 2013. - № 8. - C. $34-40$.

3. The pathogenesis of osteoarthritis involves bone, cartilage and synovial inflammation: may estrogen be a magic bullet? / M. A. Karsdal, A. C. Bay-Jensen, K. Henriksen, C. Christiansen // Menopause Int. - 2012. - Vol. 18 (4). - P. 139-146.

\section{REFERENCES}

1. Dnistrianska, A.P. (2014). Kompleksna korektiia klinnichnykh proiaviv perymenopauzalnoho periodu u zhinok [Complex correction of clinical manifestations of perimenopausal period in women]. Zdorovye zhenshchiny - Health of a Woman, 10, 157-162 [in Ukrainian].

2. Veropotvelyan, P.N., Veropotvelyan, N.P., Markin, G.O., \& Sagan, O.S. (2013). Sovremennyy podkhod k probleme osteoporoza u zhenshchin, nakodyashikhsya $v$ klimaticheskom periode [Modern approach to the problem of osteoporosis in women in menopause]. Meditsinkiye aspekty zdorovya zhenshchiny - Medical Aspects of Women's Health, 8, 34-40 [in Russian].

3. Karsdal, M.A., Bay-Jensen, A.C., Henriksen, K., \& Christiansen, C. (2012). The pathogenesis of osteoarthritis involves bone, cartilage and synovial inflammation: may estrogen be a magic bullet? Menopause Int., 18 (4), 139-146.
4. Дегенеративно-дистрофические заболевания опорнодвигательного аппарата у женщин в климактерии / В. В. Беспоясная, Т. А. Ермоленко, Е. А. Колоденко, Т. Н. Ямилова // Медицинская реабилитация, курортология, фризиотерапия. - 2012. - № 3. - С. 52-56.

5. Вознюк Л. А. Переломи у жінок з остеопорозом в постменопаузальний період / Л. А. Вознюк // Український ревматологічний журнал. - 2013. - № 3. - С. 111.

6. Кишакевич И. Т. Влияние менопаузального остеопороза на изменения качества жизни пациенток / И. Т. Кишакевич // Здоровье женщины. - 2013. - № 5. - С. 117-119.

4. Bespoyasnaya, V.V., Ermolenko, T.A., Kolodenko, E.A., \& Yamilova, T.N. (2012). Degenerativno-distrofichiskiye zabolevaniya oporno-dvigatelnogo aparata u zhenshchin v klimakterii [Degenerative-dystrophic diseases of the musculoskeletal system in women in menopause]. Meditsinskaya reabilitatsiya, kurortologiya, fizioterapiya - Medical Rehabilitation, Balneology, Physiotherapy, 3, 52-56 [in Russian].

5. Vozniuk, L.A. (2013). Perelomy u zhinok z osteoporozom v postmenopauzalnyi period [Fracture in women with osteoporosis in the postmenopausal period]. Ukrainskyi rrevmatolohichnyi zhurnal - Ukrainian Rheumatology Journal, 3, 111 [in Ukrainian].

6. Kishakevich, I.T. (2013). Vliyaniye menopauzalnogo osteoporoza na izmeneniya kachestva zhizni patsiyentok [The effect of menopausal osteoporosis on changes in the quality of life of patients]. Zdorovye zhenshcniny - Health of a Woman, 5, 117-119. 